\title{
Contemporary interpersonal relations that demand dialogue
}

\section{KEYWORDS}

changes in contemporary

interpersonal relations, dia-

logue, homo construens, social pedagogy

\begin{abstract}
Ściupider-Młodkowska Mirosława, Contemporary interpersonal relations that demand dialogue. Culture - Society - Education no 2(16) 2019, Poznań 2019, pp. 85-93, Adam Mickiewicz University Press. ISSN 2300-0422. DOI 10.14746/kse.2019.16.6.
\end{abstract}

The aim of the article is to answer the question of why contemporary interpersonal relationships need dialogue in cultural and social transformations?

The article is based on the conclusions of the author's research carried out among a selected group of students revealing the characteristics of homo construens. Young people who took part in the research directed (constructed) the scripts of partnership and family biographies as free, original and willing to change. On the other hand, the same scripts unmasked loneliness and a huge need for recognition in the world of cultural and narcissistic demands for self-actualisation, satisfaction and a sense of fulfilment in the spheres of partnerships and family. The need for dialogue requires pedagogical support that will reveal the values of community, social groups and partnerships.

\section{Introduction}

Dialogue (from the Latin dialogus - conversation), understood as community, reciprocity, symmetry - is a challenge to social and cultural transformations, focused on the individualisation of life, and affecting interpersonal relations. It is justified

\footnotetext{
* ORCID https://orcid.org/0000-0002-8700-2249.
} 
by the clash of concepts such as: love/friendship/romance, intimacy/sexuality/ pornography/betrayal, partnership/singling/independence, conformism/self-direction, autonomy/being for others, recognition/rejection/loneliness.

The aim of the article is to briefly analyse selected cultural transformations affecting the quality of these relations. Interpersonal contacts, which participate in social and cultural transformations, reflect a number of implications of events reproduced by both culture and its recipients:

- mass participation in a perfect and false world of virtual meetings (called social validation);

- hyperconsumption or compulsive shopping (G. Ritzer);

- lack of norms of coexistence in social contacts or generic experience of modern times (M. Marody);

- private versus public conversions (tendency to voyeurism, exposing private spheres);

- ubiquitous struggle for recognition in the culture of narcissism (Ch. Lasch) and many other current transformations around relationships that may affect their general condition and reveal frustrations, neurotic emotional states, loneliness, alienation, emotional autism or emotional ascetism (Hochschild, 2009).

Some of the theoretical assumptions and methodological conclusions presented in this article were justified in scientific research on partnerships in biographies of young students (Ściupider-Młodkowska, 2018). In the article, I will highlight only some of the conclusions, due to the multiplicity of methods and research material. The most valuable method in the context of the presented topic turned out to be a method drawing on the interpretative paradigm - a comprehensive interview (Kaufmann, 2000). To put it simply, the researcher confronts common knowledge with scientific knowledge, which requires distance and dialogue both for one and the other version of reality. The interlocutors are the creators of their stories about relations in the family and relationships, they are not forced to use the question and answer form. In this way, the storytellers act as homo construens - they report stories full of symbols, language and cultural codes, in which they "construct" anew the concepts and meanings connected with love and family relationships. The comprehensive interview is closely connected with an interpretative paradigm, extremely demanding and valuable for social sciences, which does not impose any hypotheses and does not foresee any imposed findings or answers other than subjective perception and description of the narrative by the respondent themselves. Mirosława Nowak-Dziemianowicz sees a huge role in the methodology treating narrative and dialogue as the key to understanding the world, especially the world of emotions, thoughts and family and partner interpretations: 
A narrator is either an actor or an interested observer of someone's actions (...) Such treatment of narrative in pedagogy, such a meaning becomes a kind of justification for comprehensive research, research whose aim is not to search for cause and effect relations between facts defined as variables but cognition, description and understanding of the subjective worlds of human life, (...) the narrative enables insight not only into the story being told, but also into all the circumstances surrounding it, broadens the individual perspective to include a social perspective, connects the local with the global or universal. (Nowak-Dziemianowicz, 2016: 36-37)

On the other hand, the second helpful indicator of the presented topic is the earlier attempt to read "a pure dialogue in relations coined by the philosopher Martin Buber versus the unclean relation of Anthony Giddens" (Ściupider-Młodkowska, 2016: 63-72). The whole stream of existential pedagogy and its representatives focus on the strength of interpersonal relations, and they understand dialogue as a guarantor of achieving satisfaction and contentment in these relations. According to $\mathrm{M}$. Buber, the phenomenon of relations is what happens between You and Me, or love, as a responsibility of Me for You (Buber, 1992: 224). Despite the fact that contemporary love is supposed to overcome the feeling of ordinariness and invisibility in a world with a multitude of impressions, it can also hurt and close people to dialogue, as I will attempt to show in this article.

\section{Love that hurts and demands dialogue}

"Love as responsibility means accepting that we are no isolated monads, sufficient unto ourselves. Our humanity is dependent on our caring and responsible involvement with others." (Weeks, 1997: 182).

Inspiration to speak about the dialogue on the level of love, which is the basis of the bonds and entire social structures, are questions about what students today think of as being together, how they define interpersonal relationships and what does family or relationship community mean to them? If these are situations, events or phenomena devaluing the notion of the Us-community in favour of concepts related to I-self-development, gathering experiences, self-improvement and celebration/adoration of the Self, as my research has shown, then how can we read anew the interpersonal relationships that are a community?

I seek answers not only in the direct influence of inevitable changes, but also in the recipients, who are constructors and directors (homo construens) of interpersonal relations, expressing readiness for responsible relations. The philosopher of dialogue, Martin Buber, believes that the maxim of love is the responsibility of 
the I for You, which is an expression of the equality of lovers, and this in turn helps them to be open and authentic (Buber, 1997: 250). Undoubtedly, love is an indicator of the ability to build lasting interpersonal bonds. At the same time, as a feeling and as a social task, it shows what has changed over the years in relations which have been invaded by the therapeutic and narcissistic cultures, which for some are creative variations of what is obsolete and traditional, and for other a love that hurts and enslaves. Many sociologists argue that today, we are entangled in a love that hurts, including Eva Illouz, Christopher Lasch, Anthony Giddens, Zygmunt Bauman, Elisabeth and Ulrich Beck, Arlie Russell Hochschild. All these authors agree that the sphere of intimacy and love is in a rivalry with the market and capitalism, technology and politics, which rationalised love, undermined its emotional intensity and agency. A calculated, utilised feeling concerns the lack of emotional involvement as coping mechanism in the face of social changes imposing codes of love. They are characterised by the lack of warm relations, cooling of bonds without closeness (Musiał, 2015) and partnership desired as a balanced commitment to acting in our roles.

I am referring mainly to the forms of short-term, ephemeral relationships, i.e. relationships strongly focused on the acquisition of individual, egoistic and one-sided desires, which require dialogue support, close and familiar, including the pedagogy of companionship (Marek, 2017), which does not recognise one-sided solutions, but above all care for the development and dignity of the person as homo construens. The need for this type of dialogue is stronger as the culture of narcissism, the market and the technicised forms of interpersonal communication become more and more apparent, and as they control and impose a new dimension of family relationships and values. Many of the abovementioned authors feel that the responsibility for this new dimension lies not only with the past and the so-called toxic bond in early childhood, but above all the instrumentalised market mechanisms that manipulate the individual and their desires. A narcissistic vision of oneself, which includes the so-called "obsession with temporality" that is, "fast consuming - the life of one's own and someone else's, body, sensations, things, skills, employees, and the pursuit of novelty and change" (Romaniszyn, 2011: 198), is embedded in the society of risk. A person in pursuit of the so-called happy life falls into the trap of putting the need to possess and to be important above the need to love, wealth above wisdom, admiration and publicity above dignity, which can lead to alienation, emptiness and loneliness.

Zygmunt Bauman warns against a way of life that takes on an externally controllable character and confirms the sense of action only among people who are 
admired, beautiful, charming, powerful, those who appear on posters, but are imprisoned by manipulation and play of appearances (Bauman, 2012: 45). A person who is ready for partnership and dialogue with others, is reflective, not subject to infantile experiences, impulses, emotionally mature, holistic, beyond any external manipulation. Such an attitude will protect them from the influence of all omnipresent forms of "boosting the Ego of the individual", which reject bonds, hurt partners, and insist on the need for constant change without deeper reflection on the authentic value of encounters with others.

\section{"Ego boosters" as community substitutes}

The conclusions of studies (Ściupider-Młodkowska, 2016: 188-249) conducted over four years (2011-2014) show that young people aged 22-25 participating in the interviews directed ("constructed") relationship and family biographies as free, original and open to change. On the other hand, the same scripts disclosed a huge need for "boosting", shining in the world of cultural and narcissistic demands. Young people wanted to follow the example of celebrities to strive for self-fulfilment, the sense of happiness in relationship defined by some as full of sexual impressions, individual choices, entertainment, constant changes of partners and setting expectations towards the partner. The narratives of the postmodern scripts have revealed a strong need for dialogue between social expectations and the needs of young people, which in turn is a task for social pedagogy to reread their needs and educate them to reflect. This can only be done with the intellectual and emotional support of young people who are creators and therefore have a great need for agency, who will be able to distinguish between egoistic and destructive behaviours and responsible behaviours, which determine dialogue and form the foundation for authentic ties.

The qualitative part of the research, conducted, among others, through twenty comprehensive interviews and conversations during the "Intimacy Between Being Together and Being Separate" classes, showed the extent to which the culture of narcissism influences the choices made by young people concerning partner relations. Conversations with students revealed all the changes, including many positive ones, such as taking care of the quality of relations, a shared, partnership-based division of duties and responsibility for building bonds, as well as negative ones, those related to audial autism, a phenomenon where virtual contacts become more attractive than real contacts, which leads to the disintegration of real relationships and the drama of entire families. 
Significant changes were also noted in the approach to searching for a partner, especially among women, who are increasingly turning social capital into sexual capital and one desired by the mass media. Lack of reflection and awareness of what deep relationships mean, reduces them to good fun and short-term pleasure, which in turn is supposed to be helped by an attractive appearance. This situation gives rise to considerable problems, not only diminishing the femininity/ masculinity of young partners, but also significantly accelerating behaviour in the intimate sphere, in which there is no room for privacy, dignity and respect. As a result of social media, something that used to be private is now being made public. Young people, lost and attracted by the offers of a wonderful, happy life, seek recognition, want to be admired and adored. They are helped with this social validation by all the social networking sites that boost the Ego. Facebook is a perfect example of the clash of reflexive identity with infantile treatment that encourages users to narcissistically stare at themselves and others. The style of functioning on this portal forces users into voyeurism - watching and peeping at private events and to permanently improve their Self on their basis. Joseph Walther, a professor at the University of California who has for years been studying the impact of virtual communication on the functioning of people in different social spaces, created a theory of the "hyperpersonal model", in which the sender of a virtual message, using tools, manipulates the message and the image of themselves, and as homo construens creates a hyperpersonality that does not recognise and does not have natural defects and imperfections. In a world of constant adrenaline - continuous shocking and bombardment by other external information, users are convinced that it is right and necessary to present oneself as a hyperpesonalities who are always in a positive mood. Publication of coloured events from one's life - all attempts at retouching and describing oneself only from a positive and extremely interesting, though not always truthful side, is aimed at opposing being boring, mute and unnoticed - is a kind of struggle for recognition. The ego-boosting instruments of shocking others with one's unique hobbies, extraordinary ways spending of time with one's beloved dog, unique posts and beautifully retouched, though untrue, photos translate into the quality of interpersonal relations.

Visible instrumental treatment of others in schools, entertainment venues, judging people solely from the perspective of their appearance and what they post about themselves on the web, lead to the cementing of superficial, occasional, irresponsible and immature relational patterns. Such relations have nothing to do with the Buberian dialogue, because they do not take responsibility for the reactions or emotions of the people who participate in them. Partners who succumb to and transfer certain patterns of behaviour to the like/do not like polarity are willing to 
break up a real relationship using code borrowed from a social portal, thus they do not confront the person who is near and dear to them, because the communication system does it for them. Partners operating in such schemes know that nothing is forever - they can always end their relationship without a responsible decision to part, which on the one hand motivates them to make greater efforts for sustainability and quality of being together, on the other hand, brings a fear of abandonment. A relationship for a definite period results in the cooling down of passions, and the withdrawal from the decision to create an Us relationship. Among young people, there is often, as in the case of mythological Narcissus, a panicked fear of rejection, a panicked search for recognition and acceptance. This may be the result of a lack of real acceptance by those close to me, I am only as valuable as others consider me necessary and valuable. The world of virtual magic of communicating information about oneself adds verve and enhances the desire to shine.

The Internet gives the possibility of a vision of the preferred Self, being on the one hand anonymous, and on the other hand wishing to be unique and appreciated at all costs. This phenomenon is described, among other things, by Katarzyna Nosowska, a singer recognised in the world of show business and a keen observer and poet, who describes the phenomena of the contemporary world and is recognised in the world of show business:

You look around the world and see clearly the people who radiate a special glow. You want to shine too. (...) Now you can decide who you want to be if you don't like yourself. (...) If you want to fool everyone into believing that you are really special, take a picture with an ambitious book, say that you only listen to jazz, and at exhibitions of contemporary art say 'hmm...' with the expression of a connoisseur (...). (Nosowska, 2018: 164-165)

The author aptly describes how Facebook redefined the concept of an acquaintance or "friend":

You get the feeling you know someone because you know how they arrange products on a plate. You see them with their head on their pillow. You could get from the dining room to the kitchen in their flat because you know the way from photos. You know that a friend's cat scratched up her couch, her boyfriend ran four kilometres and her mother went to Egypt. (Nosowska, 2018: 166)

In order not to become a sensory cyborg manipulated by the interface system and consumption, there is a particular need for education that will teach dialogue and community, thus helping people not to be manipulated by cultural narcissism. "The condition for resistance and defence of subjectivity is to work on one's own intellectual, emotional and moral development” (Romaniszyn, 2011: 219). 
This is simultaneously protection against the mass media expansion of the so-called measures aimed at "improving" and "boosting" one's identity. There are known practices and coaching methods available in the media, which hurry to help anyone who wants change. The indicator of this change is possession - of a better wife, better flat, better car, better professional life. For this purpose, various techniques are used to objectify people, rank them according to category and rank of possession.

Among the values still desired by Poles, surveys document that happy family life is a priority, and next to it is the lack of a need to establish and cultivate ties with other people. The appreciated values of love and family do not exclude egoistic aspirations to satisfy, first of all, one's own good, while treating one's loved ones instrumentally. The desire for love is often not synonymous with the emotional readiness to give this love to others, even to one's children, not to mention the readiness to accept love with reciprocity, which is necessary in building a shared space of partner and family life.

\section{Conclusions}

Dialogue, as a rule, is connected with the notion of freedom and thus with full respect and acceptance. Thinking and acting dialogically does not mean fighting and replacing one dominant model of reasoning with another, but rather trying to include reflection, develop divergences and perceive possible risks and benefits. Considerations taken in this article have revealed the need for educational and support activities for people experiencing emotional and existential problems, as a result of negative experiences with virtual, ephemeral relationships. Phantasmic relations, present in the world of virtual meetings, being a substitute for real relations, lead not only to communication disorders, but may also affect identity disorders.

An interesting and extremely helpful current of dialogue counselling aims to enable independent dialogue that is free from all patterns and stereotypes mental choices. Social pedagogy, open to dialogue, provides intellectual and emotional support in order not to fight the problems that may be a problem in our subjective narrative, but to try to understand and describe them.

Education to build lasting relationships that will enable the family to survive is a serious task for social pedagogy that cares humanity, its continuity and dignity.

Social educators study and observe phenomena appearing in the space of relations, such as sexting, cyberstalking, Internet cheating, depression and loneliness 
among young people. I think that the influence of the culture of narcissism on noticeable phenomena is significant. The need for education in the direction of dialogue is all the stronger in order to change the subjective and egoistic attitude in relations into community and partnership.

\section{Bibliography}

Bauman Z. (2012), Sztuka życia, Kraków.

Bauman Z. (2018), Retrotopia, Warszawa.

Buber M. (1992), Ja i Ty, Warszawa.

Czerner A., Nieroba E. (eds.) (2011), Studia z socjologii emocji. Podręcznik akademicki, Opole.

Giddens A. (2002), Przemiany intymności. Seksualność, miłość i erotyzm we wspótczesnych społeczeństwach, Warszawa.

Hochschild A.R. (2009), Zarządzanie emocjami, komercjalizacja ludzkich uczuć, Warszawa.

Illouz E. (2016), Dlaczego miłość rani. Studium socjologiczne, Warszawa.

Kaufmann J.-C.(2000), Wywiad rozumiejacy, Warszawa.

Kaufmann J.-C. (2012), Niezwykła historia szczesśliwej miłości, Warszawa.

Lasch Ch. (2015), Kultura narcyzmu: amerykańskie życie w czasach malejących oczekiwań, Warszawa.

Marek Z. (2017), Pedagogika towarzyszenia. Perspektywa tradycji ignacjańskiej, Kraków.

Marody M. (2016), Jednostka po nowoczesności: perspektywa socjologiczna, Warszawa.

Melosik Z. (2013), Kultura popularna i tożsamość młodzieży. W niewoli władzy i wolności, Kraków.

Musiał M. (2015), Intymność i jej współczesne przemiany: studium z filozofii kultury, Kraków.

Nowak-Dziemianowicz M. (2016), Walka o uznanie w narracjach. Jednostka i wspólnota w procesie poszukiwania tożsamości, Wrocław.

Nosowska K. (2018), A ja żem jej powiedziałam, Warszawa.

Romaniszyn K. (2011), Zmysłowy cyborg - człowiek w dobie konsumpcjonizmu, [in:] A. Czerner, E. Nieroba (eds.), Sudia z socjologii emocji. Podręcznik akademicki, Opole, pp. 187-212.

Stasińska A. (2018), Socjologia pary. Praktyki intymne w związkach nieheteroseksualnych, Kraków.

Szlendak T. (2010), Socjologia rodziny. Ewolucja, historia, zróżnicowanie, Warszawa.

Ściupider-Młodkowska (2012), Relacje partnerskie w ponowoczesności, czyli o turbulencjach w intymności, Roczniki Socjologii Rodziny vol. 22.

Ściupider-Młodkowska M. (2018), Miłość w epoce Ja. Studium socjopedagogiczne, Poznań.

Tichner J., (1993), Miłość niemiłowana, Kraków. 
